\title{
Chloride homeostasis and GABA signaling in temporal lobe epilepsy
}

\author{
Richard Miles ${ }^{1}$ \\ Peter Blaesse $^{2}$ \\ Gilles Huberfeld ${ }^{1,3}$ \\ Lucia Wittner ${ }^{4}$ \\ Kai Kaila ${ }^{2}$ \\ ${ }^{1}$ Cortex \& Epilepsy, CRICM, INSERM UMRS975, CNRS UMR7225, UPMC, Paris, France \\ 2 Department of Biosciences and Neuroscience Center, University of Helsinki, Finland \\ ${ }^{3}$ Unite d'Epileptologie \& Departement de Neurophysiologie, CHU Pitié-Salpêtrière, UPMC, AP-HP, Paris, \\ France \\ ${ }^{4}$ Institute for Psychology, Hungarian Academy of Sciences, Budapest, Hungary
}

\section{Abstract}

Changes in neuronal chloride homeostasis affect $\mathrm{GABA}_{\mathrm{A}}$ receptor-mediated transmission and may contribute to epileptic activities. Work on human epileptic tissue suggests that $\mathrm{Cl}^{-}$homeostasis is impaired in some temporal lobe pyramidal cells. GABAergic depolarization of these neurons contributes to rhythmic, interictal events. Intra-neuronal $\mathrm{Cl}^{-}$is controlled in part by two electroneutral cation-chloride cotransporters. NKCC1 mediates $\mathrm{Cl}^{-}$influx, while $\mathrm{KCC} 2$ extrudes $\mathrm{Cl}^{-}$thus assuring that GABAergic signals hyperpolarize neurons. After stress, such as trauma or denervation, the expression and/or function of the cotransporters are altered. $\mathrm{KCC} 2$ is down-regulated in some pyramidal cells from both patients with temporal lobe epilepsy and animals with acquired focal epilepsies. The resulting depolarising GABAergic signals contribute to the generation of interictallike activity. Is a defective $\mathrm{Cl}^{-}$homeostasis also crucial for the genesis of ictal events? Ictal discharges are associated with intense interneuron firing and activation of GABA receptors. Depolarizing responses to GABA are evident during ictal events generated by convulsants in both animal epilepsy models and human tissue. $\mathrm{K}-\mathrm{Cl}$ cotransport by $\mathrm{KCC} 2$ is increased by the $\mathrm{Cl}^{-}$load in neurons. Paradoxically, the resulting increase in extracellular $\mathrm{K}^{+}$generates a prolonged depolarization that may sustain seizure discharges.

Defects in GABAergic signaling have often been linked to the epilepsies. Suppressing fast inhibition mediated by $\mathrm{GABA}_{\mathrm{A}}$ receptors initiates interictal-like activities in healthy brain tissue $^{1,2}$ and specific subgroups of interneurones seem to be especially sensitive to the neuronal death associated with temporal lobe epileptic syndromes ${ }^{3-5}$. However, defects in the neuronal homeostasis of chloride have only recently been linked to epileptiform activities. Intraneuronal levels of chloride control GABAergic signaling post-synaptically ${ }^{6}$. So changes in chloride homeostasis can affect the strength and even the sign of GABAergic signals. We will describe work on tissue from patients with pharmaco-resistant epilepsies of the temporal lobe which provided the first insight that chloride homeostasis might be altered in the epilepsies ${ }^{7,8}$. We will examine molecules that control chloride homeostasis, evidence that they are modulated by pathological stressors including denervation, anoxia and the sclerotic cell death associated with some focal epilepsies. We ask whether changes in chloride homeostasis contribute to ictal events, arguing that potassium efflux mediated by K-Cl cotransporters may contribute to a prolonged ictal excitation. Finally, we examine how differences in chloride 
regulation may contribute to neonatal epilepsies and ask whether molecules targeting chloride homeostasis might be effective anti-epileptic drugs.

\section{HUMAN INTERICTAL ACTIVITY AND CI-HOMEOSTASIS}

The first hint of a link between defects in Cl-homeostasis and temporal lobe epilepsy (TLE) emerged in work on slices of tissue from adult patients ${ }^{7}$. The subiculum, downstream from the sclerotic CA1 region, generated a spontaneous interictal-like activity. This population synchrony was suppressed by either GABAergic or glutamatergic antagonists, suggesting that both transmitter systems were involved in its expression. Depolarized reversal potentials for isolated GABA-mediated synaptic events in some subicular pyramidal cells suggested that $\mathrm{Cl}$ homeostasis was altered.

More specific evidence of changes in Cl-homeostasis in brain tissue from patients with TLE, from in situ hybridisation and immunostaining, suggests expression of two cotransporter molecules, $\mathrm{NKCC} 1$ and $\mathrm{KCC} 2$ may be altered. Expression of the $\mathrm{Na}-\mathrm{K}-2 \mathrm{Cl}$ cotransporter, $\mathrm{NKCC}^{9}$, which usually functions to import $\mathrm{Cl}^{-}$, appears to be increased in epileptic tissue, while expression of the $\mathrm{Cl}$-extruding $\mathrm{K}-\mathrm{Cl}$ cotransporter, $\mathrm{KCC} 2{ }^{10}$, seems to be reduced $^{8,11,12}$. NKCC1 appears to be functional in tissue from adult TLE patients and contributes to the genesis of interictal activity ${ }^{8}$. Earlier work on human epileptic tissue, showed some evidence suggestive of changes in $\mathrm{Cl}$-homeostasis ${ }^{13,14}$. Later results, from slice and animal models of focal epilepsies have confirmed that changes in Cl-homeostasis can contribute to epileptiform activities by reducing the strength of hyperpolarizing GABAergic signaling, sometimes resulting in depolarizing responses ${ }^{15-17}$.

However, cellular studies in human tissue reveal a situation more complex than a uniform down-regulation of $\mathrm{KCC} 2$ and up-regulation of NKCC1. Firstly, GABA reversal potential $\left(\mathrm{E}_{\mathrm{GABA}}\right)$ differs between cells suggesting that basal Cl-homeostasis is not affected similarly in all neurones. Instead there is quite a wide variation in driving force for GABAergic inhibition: in most principal cells it remains hyperpolarizing while GABAergic events depolarize only a minority of $\sim 20 \%$ of subicular pyramidal cells (Figure 1). The proportion of cells depolarized during interictal events was similar to that of cells where $\mathrm{E}_{\mathrm{GABA}}$ was depolarized with respect to resting potential ${ }^{8}$. Secondly, immunostaining reveals no KCC2 signal in only a proportion of this minority of cells ${ }^{8}$. Perhaps low levels of KCC2 in some neurones of this interictal network cannot effectively assure hyperpolarizing responses to GABA, possibly $\mathrm{KCC} 2$ is expressed but inactivated by post-transcriptional mechanisms, perhaps other Cl-regulating molecules are involved. Thirdly, while changes in Cl-homeostasis seem to account for the generation of interictal-like activity in the subiculum, distinct mechanisms, possibly involving rearrangements in excitatory synaptic connectivity, may be responsible for a distinct interictal-like activity generated in the CA2 region ${ }^{18}$. Finally mechanisms of the interictal population synchrony remain to be explored. A population activity dependent on both GABAergic and glutamatergic signaling seems at first similar to the giant depolarizing potentials (GDPs) of immature hippocampus ${ }^{19}$ where interneurones may play a permissive role in rhythmogenesis ${ }^{20,21}$. However interictal events of human epileptic tissue seem to be initiated by inhibitory cell firing ${ }^{22}$, suggesting some interneurones should induce principal cell firing in the human epileptic subiculum. 
Pyramidal inhibited
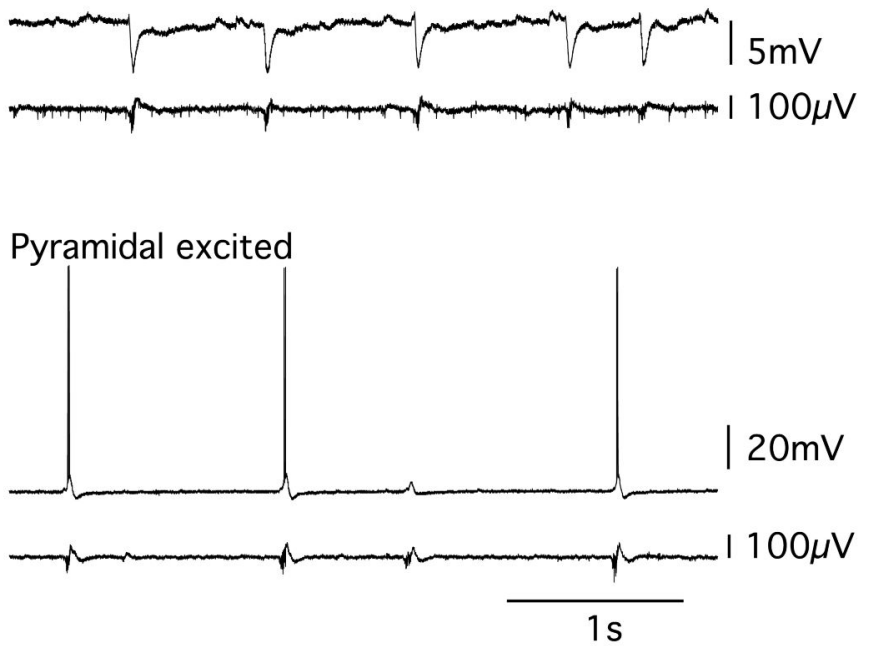
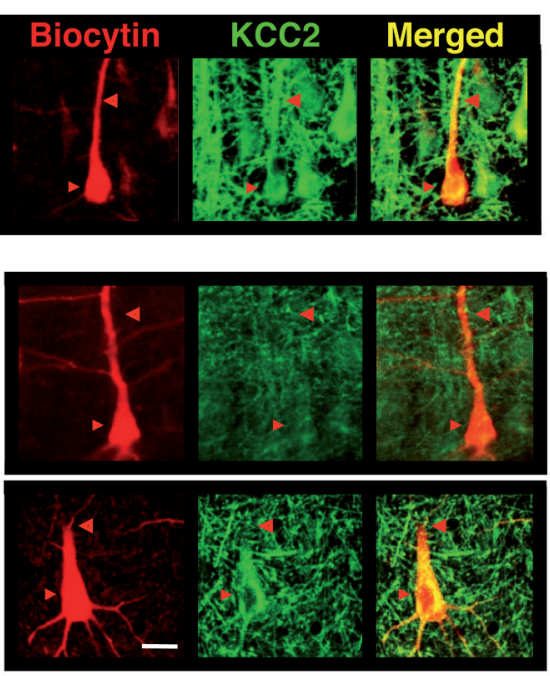

$10 \mu \mathrm{m}$

Figure 1. Correlation of pyramidal cell behavior during interical discharges with KCC2 expression in the human postoperative subiculum

(A) Combined intracellular (top trace) and extracellular recordings (bottom trace) of a pyramidal cell inhibited by GABA $(\approx 80 \%$, upper recording) and a pyramidal cell depolarized and excited by GABA $(\approx 20 \%$, lower recording) during interictal events.

(B) Immunostaining for KCC2 (green) in cells identified by biocytin filling (red). All cells hyperpolarized during epileptiform events expressed KCC2 (yellow on merging, top cell). Most cells depolarized during interictal discharges did not express KCC2 (middle cell) but some of them have a clear staining for $\mathrm{KCC} 2$ (bottom cell).

Modified from 7,8 .

\section{GABA AND $\mathrm{Cl}^{-}$REGULATION SYSTEMS}

These data point to a defect in GABAergic signaling due to altered Cl-homeostasis in some epilepsies. Neuronal Cl-homeostasis depends in part on Cation Chloride Cotransporters (CCCs). They are glycoproteins with 12 membrane-spanning segments and two cytosolic termini ${ }^{23,24}$. Adult pyramidal neurons are known to express the $\mathrm{Na}-\mathrm{K}-2 \mathrm{Cl}$ cotransporter (NKCC1) and the $\mathrm{K}-\mathrm{Cl}$ cotransporter isoforms, $\mathrm{KCC} 2$ and $\mathrm{KCC} 3{ }^{25}$. The $\mathrm{KCC} 2$ isoform is exclusively expressed in central neurons. Alternatively spliced variants may support distinct regulatory mechanisms, via phosphorylation for instance, but their physiological role is unclear. The available evidence suggests that CCCs exist as homodimers in vivo and dimerization probably plays a role in the regulation of their function ${ }^{26-28}$.

Neuronal CCCs are secondary transporters that do not consume ATP but rather derive energy for ion transport from gradients established by the Na-K ATPase. Thus, $\mathrm{Cl}^{-}$extrusion via KCCs is driven by the $\mathrm{K}^{+}$gradient, while NKCC1-mediated $\mathrm{Cl}^{-}$uptake depends on the $\mathrm{Na}^{+}$ gradient ${ }^{29-31}$. Since KCC2 operates close to its thermodynamic equilibrium, even a small increase in extracellular $\mathrm{K}^{+}$will reverse transport, from $\mathrm{Cl}^{-}$efflux to influx. Even so, activitydependent increases in internal $\mathrm{Cl}^{-}$shift the equilibrium so that $\mathrm{KCC} 2$ may induce large transient increases in external $\mathrm{K}^{+}$. CCCs are electroneutral with a stoichiometry for KCCs of $1: 1 ; \mathrm{K}: \mathrm{Cl}$ and for $\mathrm{NKCC} 1$ of 1:1:2; $\mathrm{Na}: \mathrm{K}: \mathrm{Cl}$. Thus electrophysiological methods cannot directly measure $\mathrm{CCC}$ transport. Most work has relied instead on Cl-permeable channels, such as $\mathrm{GABA}_{\mathrm{A}}$ and glycine receptors, to estimate intracellular $\mathrm{Cl}^{-}$which has also been measured with specific optical probes ${ }^{32-34}$. 
Synaptic events mediated by GABA or glycine have often been used to assess cotransporter function, but two reservations should be noted. First, while the basal IPSP reversal potential is related to cotransporter action, function is better measured by imposing a defined $\mathrm{Cl}^{-}$load on a neuron and measuring the consequent shift of $\mathrm{E}_{\mathrm{GABA}}{ }^{6,35,36}$. A second distinct point is that the direction - hyperpolarizing or depolarizing - of post-synaptic potential changes provoked by a GABA or glycine mediated synaptic event does not completely describe its effects on post-synaptic excitability. The conductance increase due to receptor activation reduces local excitability at the synaptic site, whether the membrane is depolarized or hyperpolarized $^{37,38}$.

An adequate pharmacology would facilitate work on the function of these cotransporters. The loop diuretic furosemide blocks both $\mathrm{NKCC} 1$ and $\mathrm{KCC}$ with similar potency at millimolar (mM) concentrations, but also affects N-methyl D-aspartate (NMDA) and $\mathrm{GABA}_{\mathrm{A}}$ receptors ${ }^{39}$. The diuretic, bumetanide, has a much higher affinity for NKCC1 than for KCC2 and $1-10 \mathrm{uM}$ provides a selective inhibition ${ }^{24}$. Intracellular $\mathrm{Cs}^{+}$, sometimes used in pipette solutions to enhance space clamp, is an antagonist of $\mathrm{KCC}^{24,40}$.

NKCC1 and KCC2 seem to be expressed at distinct subcellular neuronal sites. Immunohistochemistry shows significant expression of $\mathrm{KCC} 2$ on somatic and dendritic membrane including spines but not at axonal sites ${ }^{41,42}$. This localization agrees with point measurements of $\mathrm{E}_{\mathrm{GABA}}{ }^{43-45}$. $\mathrm{KCC} 2$ expression by dendritic spines may contribute to morphogenic functions. $\mathrm{KCC} 2$ interacts with the cytoskeleton and may be involved in neuronal maturation ${ }^{46}$ and specifically in spine formation ${ }^{47}$. Defining patterns of neuronal NKCC1 expression is difficult due to a questionable specificity of available antibodies ${ }^{25}$.

A heterogenous membrane expression of $\mathrm{KCC} 2$ and $\mathrm{NKCC} 1$, should impose gradients in subcellular $\mathrm{Cl}^{-}$and so generate differences in basal $\mathrm{E}_{\mathrm{GABA}}$ at different neuronal sites. Indeed physiological data suggests an NKCC1-mediated $\mathrm{Cl}^{-}$import may occur at the axon initial segment of mature neurons. Depolarized reversal potentials have been measured for GABAergic synaptic events induced by axo-axonic cells ${ }^{43,45}$ and responses to $\mathrm{GABA}^{44,48}$ at the axon initial segment. However $\mathrm{E}_{\mathrm{GABA}}$ is typically measured from somatic responses to the activation of GABAergic synapses and axo-axonic inputs may have a relative small influence on this value. Other transporters, including the $\mathrm{Cl}^{-} / \mathrm{HCO}_{3}{ }^{-}$exchanger, $\mathrm{AE} 3$, may also contribute to control of somatic levels of $\mathrm{Cl}^{-44}$.

The $\mathrm{GABA}_{\mathrm{A}}$ receptor is permeable to $\mathrm{HCO}_{3}{ }^{-}$as well as $\mathrm{Cl}^{-} 49,50$. $\mathrm{HCO}_{3}{ }^{-}$carries significant current, which may exceed $\mathrm{Cl}^{-}$currents in neurons with especially hyperpolarized resting potentials in vitro ${ }^{51}$. Resting membrane potential $\left(\mathrm{V}_{\mathrm{m}}\right)$ is more positive in hippocampal neurons in vitro, so their $\mathrm{E}_{\mathrm{GABA}}$ values are less strongly influenced by the $\mathrm{HCO}_{3}{ }^{-}$current ${ }^{6}$. Slice preparation may affect internal $\mathrm{Cl}^{-}$values ${ }^{52}$ and of course values of $\mathrm{E}_{\mathrm{GABA}}$ determined for neurons in slices do not provide accurate data on $\mathrm{E}_{\mathrm{GABA}}$ values in the intact animal, where $\mathrm{Cl}$ loads may be much higher.

\section{CHANGES IN Cl- REGULATING SYSTEMS IN PATHOLOGICAL STATES}

Neuronal Cl-regulation is affected in multiple pathophysiological conditions ${ }^{53,54}$. KCC2 expression is down-regulated, leading to a decreased efficacy of inhibition, or even to excitatory actions of GABA, in response to kindling ${ }^{55}$, in models of concussion ${ }^{56}$, and by ischemia $^{57-59}$, after axotomy ${ }^{60,61}$, after mechanical isolation of the neocortex ${ }^{16}$, and in nerve section models of chronic spinal pain ${ }^{62-64}$. Such trauma-induced down-regulation of KCC2 is often accompanied by an up-regulation of $\mathrm{NKCC}^{8,65}$.

Thus the acquired epilepsies ${ }^{17}$ may be a particular example of a more general response to brain trauma. Possibly, changes in $\mathrm{KCC} 2$ and $\mathrm{NKCC} 1$ expression and function participate in 
epileptogenesis, alternatively they may be protective or adaptive mechanisms triggered by the trauma. Thus the down-regulation of KCC 2 could usefully decrease energy expenditure in pathological states associated with an energy deficit ${ }^{25}$. In a similar way, the Na-K ATPase is down-regulated by neuronal damage ${ }^{66,67}$. Alternatively, changes in Cl-homeostasis could contribute to more general processes of neuronal de-differentiation induced by trauma. They may, for instance, tend to promote rewiring of damaged circuitry for recovery ${ }^{7,24}$.

In these diverse traumatic situations, $\mathrm{KCC} 2$ down-regulation may be related to activation of the TrkB receptor by BDNF (Brain Derived Nerve growth Factor) ${ }^{62}$. Exogenously applied BDNF was first shown to down-regulate $\mathrm{KCC} 2$ via TrkB receptors in culture ${ }^{55}$. Similarly, following epileptiform activity induced by zero-magnesium, the efficacy of $\mathrm{Cl}^{-}$extrusion is reduced in parallel with $\mathrm{KCC} 2$ down-regulation ${ }^{36}$, a mechanism aggravated by $\mathrm{NKCC} 1$ dependent $\mathrm{Cl}^{-}$import ${ }^{52}$. Work with animals expressing specific point mutations of the TrkB receptor has shown that both the Shc/FRS-2 (src homology 2 domain containing transforming protein/FGF receptor substrate 2) and PLC $\gamma$ CREB (phospholipase C $\gamma$-cAMP response element-binding)pathways must be activated to reduce $\mathrm{KCC} 2$ transcription. In contrast, the activation of Shc/FRS-2 alone via the TrkB receptor enhances KCC2 synthesis $^{36}$. This observation points to divergent actions of BDNF on neuronal $\mathrm{Cl}^{-}$regulation. It could explain how BDNF exerts opposing actions on $\mathrm{KCC} 2$ synthesis in mature and immature, or in intact and damaged neurons ${ }^{65}$. The source of the BDNF involved in the different forms of trauma is not always clear. BDNF is secreted by various types of neurons ${ }^{68}$. It seems more likely however, that the BDNF involved in responses to de-afferentation is liberated by activated microglia. In a nerve section model of spinal neuropathic pain, microglia migrate to sites of damage and liberate BDNF thus altering $\mathrm{Cl}$-homeostasis via TrkB receptors ${ }^{62,63}$.

In these studies, traumatic stimuli reduce $\mathrm{KCC} 2$ transcription and thus the total cellular pool of the transporter, typically measured by immunoblots of the protein. However, KCC2 function depends on the fraction of cellular protein present in the cell membrane, rather than the total protein pool. Thus, as for other transporters, changes in membrane trafficking contribute crucially to $\mathrm{KCC} 2$ function ${ }^{69,70}$. Cotransporter function might also be modulated by changes in the intrinsic ion-transport rate, but details of whether and how this parameter is modulated are not yet clear.

$\mathrm{NKCC} 1$ and $\mathrm{KCC} 2$ function is also regulated by phosphorylation. For instance, the kinases WNK (With No lysine (K) kinase) and SPAK(Ste20p-related Proline Alanine-rich Kinase)/ OSR1 (oxidative-stress-responsive kinase1) both activate NKCC1, and inhibit $\mathrm{KCC}_{2}{ }^{71-73}$. The phosphorylation state of KCC2 is changed by trauma, oxidative stress, or epilepsy ${ }^{69,74}$. It affects trafficking including degradation ${ }^{69,70,74}$, and may alter the rate of co-transport by $\mathrm{KCC} 2^{74}$. Early work stressed a reciprocal regulation in which phosphorylation activates NKCC1 and inhibits KCCs while de-phosphorylation inhibits NKCC1 and activates $\mathrm{KCCs}^{75}$. However more recent work has shown that phosphorylation at different sites of the KCC2 molecule may exert opposing functional effects ${ }^{69,70}$.

Both short- and relatively long-term changes in transporter function can be explained by changes in membrane expression or co-transport rate due to phosphorylation state or by changes in expression due to altered transcription. But transporter function may be persistently altered over months and years after traumatic injuries and in the epilepsies ${ }^{7,8}$. One possible explanation is that of a maintained stimulus due perhaps to chronic inflammation. Maintained neuropathic pain is associated with the persistent release of pro-inflammatory cytokines and chemokines from glial cells ${ }^{76}$. Pro-inflammatory molecules are also involved in the pathogenesis of epilepsy and are present in the chronically epileptic brain ${ }^{77}$. Cells of the bloodbrain barrier, whose permeability increases after a seizure, are targets for cytokine signaling ${ }^{78}$. Thus inflammatory mechanisms may contribute to the evolution of chronic 
epilepsy ${ }^{79}$. It would be especially interesting if pro-inflammatory molecules control, directly or indirectly, neuronal cotransporter function.

\section{CI-HOMEOSTASIS AND ICTAL ACTIVITIES}

Mechanisms of initiation of ictal events in focal epilepsies are not well understood. The human condition is quite well modeled by chronic animal models such as pilocarpine or kainatetreatment ${ }^{80}$. They exhibit a similar pattern of sclerotic hippocampal cell death and show a delay between an initial convulsion and the emergence of recurring seizures. However, chronic epilepsy models have so far provided few insights into mechanisms of ictogenesis. Instead most concepts derive from work on slices from healthy animals exposed to convulsants ${ }^{81-83}$.

Recent work on the genesis of epileptiform activities has emphasized a glial contribution ${ }^{84-}$ 86 and glial control of external levels of both potassium and glutamate may be compromised in an epileptic brain ${ }^{78,87}$. However synaptic mechanisms involving both glutamatergic and GABAergic signaling certainly contribute to ictal discharges. Indeed convulsants activate interneurones particularly strongly ${ }^{88,89}$ and ictal events are suppressed by agents, such as opiate receptor agonists, that selectively reduce interneurone activity ${ }^{81}$.

The chloride flux due to high-frequency activation of inhibitory synapses engages $\mathrm{Cl}$ homeostatic mechanisms. The cotransporters KCC2 and NKCC1 may then contribute to, and even favour, seizures. If Cl-extrusion mechanisms cannot maintain low levels of intracellular chloride $^{48,90,91}$, synaptic signals mediated by inhibitory cell firing may change from hyperpolarizing to depolarizing. Such a dynamic switch should enhance and prolong an ictal event. Furthermore, even if the polarity of GABAergic events is reversed, the $\mathrm{KCC} 2$ transporter continues to export not only $\mathrm{Cl}^{-}$but also $\mathrm{K}^{+}$ions ${ }^{92}$. The strong activation of $\mathrm{GABA}_{\mathrm{A}}$ receptors during an ictal event leads to a large electrogenic uptake of $\mathrm{Cl}$ driven by the depolarizing $\mathrm{HCO}_{3}{ }^{-}$current (Figure 2). The resulting surge in external $\mathrm{K}^{+93}$ adds to that due to massive neuronal firing. It increases neuronal excitability at both somato-dendritic and also axonal sites with a consequent increase in antidromic firing ${ }^{94,95}$. The water influx into cells tends to reduce extracellular volume, enhances ephaptic neuronal interactions and increases local concentrations of glutamate and $\mathrm{K}^{+96}$.

A

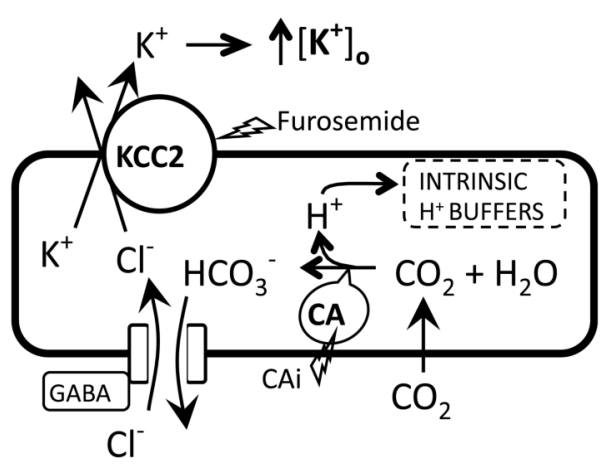

B

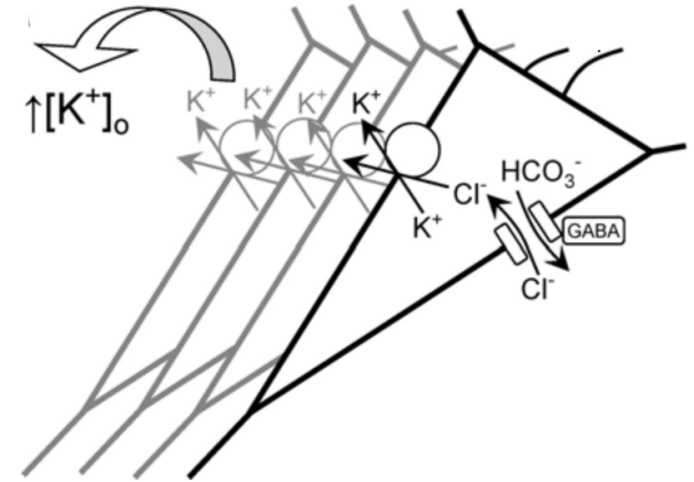

Figure 2. KCC2 in the generation of seizure-promoting $\left[\mathrm{K}^{+}\right]_{0}$ transients (A) $\mathrm{HCO}_{3}{ }^{-}$efflux via $\mathrm{GABA}_{4}$ receptor's channel causes a depolarization of the membrane potential that drives a conductive uptake of $\mathrm{Cl}^{-}$, and net hydration of $\mathrm{CO}_{2}$ catalyzed by cytosolic carbonic anhydrase (CA) replenishes $\mathrm{HCO}_{3}{ }^{-}$during its efflux ${ }^{50} . \mathrm{H}^{+}$ions are produced at the same rate as $\mathrm{HCO}_{3}{ }^{-}$ions and bound by intrinsic cytosolic buffers, which is essential in the maintenance of the $\mathrm{HCO}_{3}{ }^{-}$electrochemical gradient during prolonged GABAA receptors activation. The $\mathrm{HCO}_{3}{ }^{-}$-dependent intra-neuronal accumulation of $\mathrm{Cl}^{-}$drives $\mathrm{K}-\mathrm{Cl}$ cotransport by $\mathrm{KCC} 2$, thereby giving rise to a net efflux of $\mathrm{K}^{+}$. (B) During intense 
activation of GABAA receptors in a population of neurons, the $\mathrm{KCC} 2$-mediated net efflux of $\mathrm{K}^{+}$can be large enough to lead to a large increase $\left[\mathrm{K}^{+}\right]_{\mathrm{o}}$, which is a characteristic feature of seizure activity. Note that the chain of events depicted in $\boldsymbol{A}$ can be blocked by furosemide or by membrane-permeable carbonic anhydrase inhibitors (CAi), both of which are known to exert anticonvulsant actions.

Modified from 93 .

A seizure-promoting action of $\mathrm{KCC} 2$ due to an increase in external $\mathrm{K}^{+}$is also consistent with the anticonvulsant actions of carbonic anhydrase (CA) inhibitors. Intracellular CA activity is needed to replenish the $\mathrm{HCO}_{3}{ }^{-}$and drive further $\mathrm{Cl}^{-}$uptake ${ }^{50,93}$. A KCC2-mediated extracellular $\mathrm{K}^{+}$transient may also partly explain the anti-convulsant actions of furosemide ${ }^{97,98}$. However elevated extracellular $\mathrm{K}^{+99}$ reverses KCC2 co-transport of $\mathrm{K}$ and $\mathrm{Cl}^{75}$ so the surge in external $\mathrm{K}^{+}$should be self-limiting.

\section{CI-REGULATION AND EPILEPTIFORM ACTIVITIES IN THE YOUNG}

In contrast to the adult brain, seizure activity in neonatal rat hippocampus up-regulates $\mathrm{KCC} 2$ activity via activation of TrkB receptors ${ }^{100}$. Interestingly, TrkB may also trigger events that enhance $\mathrm{KCC} 2$ expression in the normal neonate, so initiating the hyperpolarizing shift of $\mathrm{E}_{\mathrm{GABA}}$ during development ${ }^{101}$. BDNF-TrkB signaling also affects $\mathrm{GABA}_{\mathrm{A}}$ receptor trafficking: in the neonate it induces an increase in membrane $\mathrm{GABA}_{\mathrm{A}}$ receptors, but a decrease is initiated in more mature neurons ${ }^{102}$. TrkB activation then synergistically enhances both the voltage and conductance effects of GABAergic inhibition in immature neurons, but has opposite effects in the mature brain possibly due to the activation of different signaling pathways.

In the adult, an activity-dependent acidosis may be a key factor in seizure termination ${ }^{103}$. In contrast, neonatal seizures may be terminated in part by a seizure-induced increase in the efficacy of GABAergic inhibition ${ }^{100}$. We note that carbonic anhydrase is not expressed by neonatal pyramidal neurons ${ }^{104}$. In its absence, transport mediated by $\mathrm{KCC} 2$ after strong GABAergic activity during a seizure should not produce a pro-convulsant increase in extracellular $\mathrm{K}^{+}$. NKCC1 may play a key role in loading neonatal pyramidal cells with $\mathrm{Cl}^{-}$, since the antagonist bumetanide seems to suppress neonatal seizures ${ }^{105}$, and also reduces the resistance to pro-GABAergic drugs that occurs due to $\mathrm{Cl}$ accumulation during recurring ictallike events in slices ${ }^{52}$.

\section{MOLECULES REGULATING CI-HOMEOSTASIS AS TARGETS FOR ANTI-EPILEPTIC DRUGS}

There is a major need for new drug targets in temporal lobe epilepsies ${ }^{106,107}$. Might pathways controlling Cl-homeostasis be a useful target?

A compromised control of intracellular $\mathrm{Cl}$ may contribute to interictal rhythmogenesis. However, as we have discussed, residual cotransporter activity should tend to elevate extracellular $\mathrm{K}^{+}$in response to repetitive activation of inhibitory synapses and so contribute to the prolonged depolarization underlying an ictal event. Anti-epileptic drugs need to counter ictal rather than interictal events. Nevertheless there has been interest in the diuretic molecule, bumetanide $^{108}$, which can be used to block the Cl-importing cotransporter, NKCC1, without affecting the exporting transporter, $\mathrm{KCC} 2$.

Bumetanide should tend to shift the driving force for GABAergic actions in a hyperpolarizing direction. This action suffices to suppress interictal-like activity in slices of adult human epileptic tissue ${ }^{8}$. Similar results have been reported in different models of neonatal epilepsies ${ }^{52,109,110}$. However bumetanide is reported not to have anti-ictal effects in chronically epileptic animals ${ }^{111}$ and in some neonatal slice models ${ }^{111,112}$. 
It has been suggested that compounds that selectively enhance KCC2 actions should increase the efficacy of postsynaptic inhibition and thereby act as anticonvulsant drugs ${ }^{108}$.

Paradoxically, however, the role of KCC2 in promoting ictal discharges (Figure 1), suggests that the opposite may be true. Indeed, furosemide, which inhibits both KCC2 and NKCC1, has anti-epileptic actions in focal cortical epilepsies ${ }^{97,98}$, although the high doses needed to block $\mathrm{KCC} 2^{93}$ probably preclude the use of this molecule as an anticonvulsant.

Proteins that regulate the expression, trafficking and activity of the cation-chloride cotransporters may offer alternative targets for anticonvulsant drugs. In practice however, the importance of cotransporter function in regulating electrolyte balance and cell volume throughout the body implies that some means of targeting such molecules to neurons, or perhaps subsets of neurons, will also be needed

\section{References}

1. Schwartzkroin PA, Prince DA. Penicillin-induced epileptiform activity in the hippocampal in vitro prepatation. Annals of Neurology 1977;1:463-469. [PubMed: 617260]

2. Wong RK, Traub RD, Miles R. Cellular basis of neuronal synchrony in epilepsy. Advances in Neurology 1986;44:583-592. [PubMed: 3706021]

3. Magloczky Z, Freund TF. Impaired and repaired inhibitory circuits in the epileptic human hippocampus. Trends in Neurosciences 2005;28:334-340. [PubMed: 15927690]

4. Cossart R, Bernard C, Ben-Ari Y. Multiple facets of GABAergic neurons and synapses: Multiple fates of GABA signaling in epilepsies. Trends in Neurosciences 2005;28:108-115. [PubMed: 15667934]

5. Knopp A, Frahm C, Fidzinski P, Witte OW, Behr J. Loss of GABAergic neurons in the subiculum and its functional implications in temporal lobe epilepsy. Brain 2008;131:1516-1527. [PubMed: 18504292]

6. Farrant M, Kaila K. The cellular, molecular and ionic basis of GABA(A) receptor signaling. Progress in Brain Research 2007;160:59-87. [PubMed: 17499109]

7. Cohen I, Navarro V, Clemenceau S, Baulac M, Miles R. On the origin of interictal activity in human temporal lobe epilepsy in vitro. Science 2002;298:1418-1421. [PubMed: 12434059]

8. Huberfeld G, Wittner L, Clemenceau S, Baulac M, Kaila K, Miles R, Rivera C. Perturbed chloride homeostasis and GABAergic signaling in human temporal lobe epilepsy. J Neurosci 2007;27:98669873. [PubMed: 17855601]

9. Delpire E, Rauchman MI, Beier DR, Hebert SC, Gullans SR. Molecular cloning and chromosome localization of a putative basolateral $\mathrm{Na}(+)-\mathrm{K}(+)-2 \mathrm{Cl}$ - cotransporter from mouse inner medullary collecting duct (mimcd-3) cells. The Journal of Biological Chemistry 1994;269:25677-25683. [PubMed: 7929272]

10. Payne JA, Stevenson TJ, Donaldson LF. Molecular characterization of a putative K-Cl cotransporter in rat brain. A neuronal-specific isoform. The Journal of Biological Chemistry 1996;271:1624516252. [PubMed: 8663311]

11. Munoz A, Mendez P, DeFelipe J, Alvarez-Leefmans FJ. Cation-chloride cotransporters and GABAergic innervation in the human epileptic hippocampus. Epilepsia 2007;48:663-673. [PubMed: 17319917]

12. Palma E, Amici M, Sobrero F, Spinelli G, Di Angelantonio S, Ragozzino D, Mascia A, Scoppetta C, Esposito V, Miledi R, Eusebi F. Anomalous levels of Cl- transporters in the hippocampal subiculum from temporal lobe epilepsy patients make GABA excitatory. Proceedings of the National Academy of Sciences of the United States of America 2006;103:8465-8468. [PubMed: 16709666]

13. Kohling R, Lucke A, Straub H, Speckmann EJ, Tuxhorn I, Wolf P, Pannek H, Oppel F. Spontaneous sharp waves in human neocortical slices excised from epileptic patients. Brain 1998;121(Pt 6):10731087. [PubMed: 9648543]

14. Schwartzkroin PA, Knowles WD. Intracellular study of human epileptic cortex: In vitro maintenance of epileptiform activity. Science 1984;223:709-712. [PubMed: 6695179]

15. Khalilov I, Holmes GL, Ben-Ari Y. In vitro formation of a secondary epileptogenic mirror focus by interhippocampal propagation of seizures. Nature Neuroscience 2003;6:1079-1085. 
16. Jin X, Huguenard JR, Prince DA. Impaired Cl- extrusion in layer Vpyramidal neurons of chronically injured epileptogenic neocortex. Journal of Neurophysiology 2005;93:2117-2126. [PubMed: 15774713]

17. Pathak HR, Weissinger F, Terunuma M, Carlson GC, Hsu FC, Moss SJ, Coulter DA. Disrupted dentate granule cell Chloride regulation enhances synaptic excitability during development of temporal lobe epilepsy. J Neurosci 2007;27:14012-14022. [PubMed: 18094240]

18. Wittner L, Huberfeld G, Clemenceau S, Eross L, Dezamis E, Entz L, Ulbert I, Baulac M, Freund TF, Magloczky Z, Miles R. The epileptic human hippocampal Cornu Ammonis 2 region generates spontaneous interictal-like activity in vitro. Brain 2009;132:3032-3046. [PubMed: 19767413]

19. Ben-Ari Y, Cherubini E, Corradetti R, Gaiarsa JL. Giant synaptic potentials in immature rat CA3 hippocampal neurones. The Journal of Physiology 1989;416:303-325. [PubMed: 2575165]

20. Marchionni I, Omrani A, Cherubini E. In the developing rat hippocampus a tonic GABAa-mediated conductance selectively enhances the glutamatergic drive of principal cells. The Journal of Physiology 2007;581:515-528. [PubMed: 17317750]

21. Sipila ST, Huttu K, Soltesz I, Voipio J, Kaila K. Depolarizing GABAacts on intrinsically bursting pyramidal neurons to drive giant depolarizing potentials in the immature hippocampus. J Neurosci 2005;25:5280-5289. [PubMed: 15930375]

22. Huberfeld G, Menendez de la Prida L, Pallud J, Cohen I, Le Van Quyen M, Adam C, Clemenceau S, Baulac M, Miles R. Glutamatergic pre-ictal discharges emerge at the transition to seizure in human epilepsy. Nature Neurosci. 2011In press

23. Mercado A, Mount DB, Gamba G. Electroneutral Cation-Chloride cotransporters in the central nervous system. Neurochem Res 2004;29:17-25. [PubMed: 14992262]

24. Payne JA, Rivera C, Voipio J, Kaila K. Cation-Chloride cotransporters in neuronal communication, development and trauma. Trends in Neurosciences 2003;26:199-206. [PubMed: 12689771]

25. Blaesse P, Airaksinen MS, Rivera C, Kaila K. Cation-Chloride cotransporters and neuronal function. Neuron 2009;61:820-838. [PubMed: 19323993]

26. Blaesse P, Guillemin I, Schindler J, Schweizer M, Delpire E, Khiroug L, Friauf E, Nothwang HG. Oligomerization of KCC2 correlates with development of inhibitory neurotransmission. J Neurosci 2006;26:10407-10419. [PubMed: 17035525]

27. Casula S, Shmukler BE, Wilhelm S, Stuart-Tilley AK, Su W, Chernova MN, Brugnara C, Alper SL. A dominant negative mutant of the kccl k-cl cotransporter: Both $\mathrm{N}$ - and C-terminal cytoplasmic domains are required for $\mathrm{K}-\mathrm{Cl}$ cotransport activity. The Journal of Biological Chemistry 2001;276:41870-41878. [PubMed: 11551954]

28. Parvin MN, Gerelsaikhan T, Turner RJ. Regions in the cytosolic C-terminus of the secretory $\mathrm{Na}(+)$ $\mathrm{K}(+)-2 \mathrm{Cl}(-)$ cotransporter NKCC1 are required for its homodimerization. Biochemistry 2007;46:9630-9637. [PubMed: 17655331]

29. Achilles K, Okabe A, Ikeda M, Shimizu-Okabe C, Yamada J, Fukuda A, Luhmann HJ, Kilb W. Kinetic properties of $\mathrm{Cl}$ uptake mediated by $\mathrm{Na}+$-dependent $\mathrm{K}+-2 \mathrm{Cl}$ cotransport in immature rat neocortical neurons. J Neurosci 2007;27:8616-8627. [PubMed: 17687039]

30. Brumback AC, Staley KJ. Thermodynamic regulation of NKCC1-mediated Cl- cotransport underlies plasticity of GABA(a) signaling in neonatal neurons. J Neurosci 2008;28:1301-1312. [PubMed: 18256250]

31. Russell JM. Sodium-Potassium-Chloride cotransport. Physiological Reviews 2000;80:211-276. [PubMed: 10617769]

32. Arosio D, Ricci F, Marchetti L, Gualdani R, Albertazzi L, Beltram F. Simultaneous intracellular Chloride and $\mathrm{pH}$ measurements using a GFP-based sensor. Nat Methods 2010;7:516-518. [PubMed: 20581829]

33. Kuner T, Augustine GJ. A genetically encoded ratiometric indicator for Chloride: Capturing Chloride transients in cultured hippocampal neurons. Neuron 2000;27:447-459. [PubMed: 11055428]

34. Waseem T, Mukhtarov M, Buldakova S, Medina I, Bregestovski P. Genetically encoded Cl-sensor as a tool for monitoring of cl-dependent processes in small neuronal compartments. Journal of Neuroscience Methods 2010;193:14-23. [PubMed: 20705097] 
35. Khirug S, Huttu K, Ludwig A, Smirnov S, Voipio J, Rivera C, Kaila K, Khiroug L. Distinct properties of functional KCC2 expression in immature mouse hippocampal neurons in culture and in acute slices. The European Journal of Neuroscience 2005;21:899-904. [PubMed: 15787696]

36. Rivera C, Voipio J, Thomas-Crusells J, Li H, Emri Z, Sipila S, Payne JA, Minichiello L, Saarma M, Kaila K. Mechanism of activity-dependent downregulation of the neuron-specific K-Cl cotransporter KCC2. J Neurosci 2004;24:4683-4691. [PubMed: 15140939]

37. Gulledge AT, Stuart GJ. Excitatory actions of GABA in the cortex. Neuron 2003;37:299-309. [PubMed: 12546824]

38. Vida I, Bartos M, Jonas P. Shunting inhibition improves robustness of gamma oscillations in hippocampal interneuron networks by homogenizing firing rates. Neuron 2006;49:107-117. [PubMed: 16387643]

39. Staley KJ. Diuretics as antiepileptic drugs: Should we go with the flow? Epilepsy currents/American Epilepsy Society 2002;2:35-38. [PubMed: 15309160]

40. Williams JR, Payne JA. Cation transport by the neuronal $\mathrm{K}(+)-\mathrm{Cl}(-)$ cotransporter $\mathrm{KCC} 2$ : Thermodynamics and kinetics of alternate transport modes. American Journal of Physiology 2004;287:C919-931. [PubMed: 15175220]

41. Baldi R, Varga C, Tamas G. Differential distribution of KCC2 along the axo-somato-dendritic axis of hippocampal principal cells. The European Journal of Neuroscience 2010;32:1319-1325. [PubMed: 20880357]

42. Gulyas AI, Sik A, Payne JA, Kaila K, Freund TF. The Kcl cotransporter, KCC2, is highly expressed in the vicinity of excitatory synapses in the rat hippocampus. The European Journal of Neuroscience 2001;13:2205-2217. [PubMed: 11454023]

43. Szabadics J, Varga C, Molnar G, Olah S, Barzo P, Tamas G. Excitatory effect of GABAergic axoaxonic cells in cortical microcircuits. Science 2006;311:233-235. [PubMed: 16410524]

44. Khirug S, Yamada J, Afzalov R, Voipio J, Khiroug L, Kaila K. Gabaergic depolarization of the axon initial segment in cortical principal neurons is caused by the Na-K-2Cl cotransporter NKCC1. J Neurosci 2008;28:4635-4639. [PubMed: 18448640]

45. Woodruff A, Xu Q, Anderson SA, Yuste R. Depolarizing effect of neocortical chandelier neurons. Front Neural Circuits 2009;3:15. [PubMed: 19876404]

46. Horn Z, Ringstedt T, Blaesse P, Kaila K, Herlenius E. Premature expression of KCC2 in embryonic mice perturbs neural development by an ion transport-independent mechanism. The European Journal of Neuroscience 2010;31:2142-2155. [PubMed: 20529123]

47. Li H, Khirug S, Cai C, Ludwig A, Blaesse P, Kolikova J, Afzalov R, Coleman SK, Lauri S, Airaksinen MS, Keinanen K, Khiroug L, Saarma M, Kaila K, Rivera C. KCC2 interacts with the dendritic cytoskeleton to promote spine development. Neuron 2007;56:1019-1033. [PubMed: 18093524]

48. Alger BE, Nicoll RA. GABA-mediated biphasic inhibitory responses in hippocampus. Nature 1979;281:315-317. [PubMed: 551280]

49. Kaila K. Ionic basis of GABAa receptor channel function in the nervous system. Progress in Neurobiology 1994;42:489-537. [PubMed: 7522334]

50. Kaila K, Voipio J. Postsynaptic fall in intracellular $\mathrm{pH}$ induced by GABA-activated bicarbonate conductance. Nature 1987;330:163-165. [PubMed: 3670401]

51. Kaila K, Voipio J, Paalasmaa P, Pasternack M, Deisz RA. The role of bicarbonate in GABAa receptormediated IPSPs of rat neocortical neurones. The Journal of Physiology 1993;464:273-289. [PubMed: 8229801]

52. Dzhala VI, Kuchibhotla KV, Glykys JC, Kahle KT, Swiercz WB, Feng G, Kuner T, Augustine GJ, Bacskai BJ, Staley KJ. Progressive NKCC1-dependent neuronal chloride accumulation during neonatal seizures. J Neurosci 2010;30:11745-11761. [PubMed: 20810895]

53. Delpire E, Mount DB. Human and murine phenotypes associated with defects in Cation-Chloride cotransport. Annual Review of Physiology 2002;64:803-843.

54. Kahle KT, Staley KJ, Nahed BV, Gamba G, Hebert SC, Lifton RP, Mount DB. Roles of the CationChloride cotransporters in neurological disease. Nat Clin Pract Neurol 2008;4:490-503. [PubMed: 18769373]

55. Rivera C, Li H, Thomas-Crusells J, Lahtinen H, Viitanen T, Nanobashvili A, Kokaia Z, Airaksinen MS, Voipio J, Kaila K, Saarma M. BDNF-induced Trkb activation down-regulates the K+-Cl- 
cotransporter KCC2 and impairs neuronal Cl- extrusion. The Journal of Cell Biology 2002;159:747752. [PubMed: 12473684]

56. Bonislawski DP, Schwarzbach EP, Cohen AS. Brain injury impairs dentate gyrus inhibitory efficacy. Neurobiology of Disease 2007;25:163-169. [PubMed: 17045484]

57. Galeffi F, Sah R, Pond BB, George A, Schwartz-Bloom RD. Changes in intracellular Chloride after oxygen-glucose deprivation of the adult hippocampal slice: Effect of diazepam. J Neurosci 2004;24:4478-4488. [PubMed: 15128862]

58. Papp E, Rivera C, Kaila K, Freund TF. Relationship between neuronal vulnerability and PotassiumChlorideco transporter 2 immunoreactivity in hippocampus following transient forebrain ischemia. Neuroscience 2008;154:677-689. [PubMed: 18472345]

59. Jaenisch N, Witte OW, Frahm C. Downregulation of Potassium Chloride cotransporter KCC2 after transient focal cerebral ischemia. Stroke 2010;41:e151-159. [PubMed: 20044519]

60. Nabekura J, Ueno T, Okabe A, Furuta A, Iwaki T, Shimizu-Okabe C, Fukuda A, Akaike N. Reduction of KCC2 expression and GABAa receptor-mediated excitation after in vivo axonal injury. J Neurosci 2002;22:4412-4417. [PubMed: 12040048]

61. Toyoda H, Ohno K, Yamada J, Ikeda M, Okabe A, Sato K, Hashimoto K, Fukuda A. Induction of NMDA and GABAa receptor-mediated $\mathrm{Ca} 2+$ oscillations with $\mathrm{KCC} 2 \mathrm{mRNA}$ downregulation in injured facial motoneurons. Journal of Neurophysiology 2003;89:1353-1362. [PubMed: 12612004]

62. Coull JA, Beggs S, Boudreau D, Boivin D, Tsuda M, Inoue K, Gravel C, Salter MW, De Koninck Y. BDNF from microglia causes the shift in neuronal anion gradient underlying neuropathic pain. Nature 2005;438:1017-1021. [PubMed: 16355225]

63. De Koninck Y. Altered Chloride homeostasis in neurological disorders: A new target. Curr Opin Pharmacol 2007;7:93-99. [PubMed: 17182282]

64. Price TJ, Cervero F, Gold MS, Hammond DL, Prescott SA. Chloride regulation in the pain pathway. Brain Res Rev 2009;60:149-170. [PubMed: 19167425]

65. Shulga A, Thomas-Crusells J, Sigl T, Blaesse A, Mestres P, Meyer M, Yan Q, Kaila K, Saarma M, Rivera C, Giehl KM. Posttraumatic GABA(a)-mediated [Ca2+]i increase is essential for the induction of brain-derived neurotrophic factor-dependent survival of mature central neurons. J Neurosci 2008;28:6996-7005. [PubMed: 18596173]

66. Pylova SI, Majkowska J, Hilgier W, Kapuscinski A, Albrecht J. Rapid decrease of high affinity ouabain binding sites in hippocampal CA1 region following short-term global cerebral ischemia in rat. Brain research 1989;490:170-173. [PubMed: 2547499]

67. Ross ST, Soltesz I. Selective depolarization of interneurons in the early posttraumatic dentate gyrus: Involvement of the $\mathrm{Na}(+) / \mathrm{K}(+)-A T P a s e$. Journal of Neurophysiology 2000;83:2916-2930. [PubMed: 10805688]

68. Lessmann V, Brigadski T. Mechanisms, locations, and kinetics of synaptic BDNF secretion: An update. Neuroscience Research 2009;65:11-22. [PubMed: 19523993]

69. Lee HH, Jurd R, Moss SJ. Tyrosine phosphorylation regulates the membrane trafficking of the Potassium Chloride cotransporter KCC2. Mol Cell Neurosci 2010;45:173-179. [PubMed: 20600929]

70. Lee HH, Walker JA, Williams JR, Goodier RJ, Payne JA, Moss SJ. Direct protein kinase C-dependent phosphorylation regulates the cell surface stability and activity of the Potassium Chloride cotransporter KCC2. The Journal of Biological Chemistry 2007;282:29777-29784. [PubMed: 17693402]

71. Gagnon KB, England R, Delpire E. Volume sensitivity of Cation-Cl-cotransporters is modulated by the interaction of two kinases: Ste20-related proline-alanine-rich kinase and WNK4. American Journal of Physiology 2006;290:C134-142. [PubMed: 15930150]

72. Kahle KT, Rinehart J, de Los Heros P, Louvi A, Meade P, Vazquez N, Hebert SC, Gamba G, Gimenez I, Lifton RP. WNK3 modulates transport of Cl- in and out of cells: Implications for control of cell volume and neuronal excitability. Proceedings of the National Academy of Sciences of the United States of America 2005;102:16783-16788. [PubMed: 16275911]

73. Rinehart J, Maksimova YD, Tanis JE, Stone KL, Hodson CA, Zhang J, Risinger M, Pan W, Wu D, Colangelo CM, Forbush B, Joiner CH, Gulcicek EE, Gallagher PG, Lifton RP. Sites of regulated 
phosphorylation that control K-Cl cotransporter activity. Cell 2009;138:525-536. [PubMed: 19665974]

74. Wake H, Watanabe M, Moorhouse AJ, Kanematsu T, Horibe S, Matsukawa N, Asai K, Ojika K, Hirata M, Nabekura J. Early changes in KCC2 phosphorylation in response to neuronal stress result in functional downregulation. J Neurosci 2007;27:1642-1650. [PubMed: 17301172]

75. Payne JA. Functional characterization of the neuronal-specific $\mathrm{K}-\mathrm{Cl}$ cotransporter: Implications for $[\mathrm{K}+]$ o regulation. The American Journal of Physiology 1997;273:C1516-1525. [PubMed: 9374636]

76. Abbadie C, Bhangoo S, De Koninck Y, Malcangio M, Melik-Parsadaniantz S, White FA. Chemokines and pain mechanisms. Brain Res Rev 2009;60:125-134. [PubMed: 19146875]

77. Fabene PF, Bramanti P, Constantin G. The emerging role for chemokines in epilepsy. J Neuroimmunol 2010;224:22-27. [PubMed: 20542576]

78. David Y, Cacheaux LP, Ivens S, Lapilover E, Heinemann U, Kaufer D, Friedman A. Astrocytic dysfunction in epileptogenesis: Consequence of altered Potassium and glutamate homeostasis. J Neurosci 2009;29:10588-10599. [PubMed: 19710312]

79. Fabene PF, Navarro Mora G, Martinello M, Rossi B, Merigo F, Ottoboni L, Bach S, Angiari S, Benati D, Chakir A, Zanetti L, Schio F, Osculati A, Marzola P, Nicolato E, Homeister JW, Xia L, Lowe JB, McEver RP, Osculati F, Sbarbati A, Butcher EC, Constantin G. A role for leukocyte-endothelial adhesion mechanisms in epilepsy. Nature medicine 2008;14:1377-1383.

80. Pitkanen A, Lukasiuk K. Molecular and cellular basis of epileptogenesis in symptomatic epilepsy. Epilepsy Behav 2009;14(Suppl 1):16-25. [PubMed: 18835369]

81. Avoli M, Louvel J, Kurcewicz I, Pumain R, Barbarosie M. Extracellular free Potassium and calcium during synchronous activity induced by 4-AminoPyridine in the juvenile rat hippocampus. The Journal of Physiology 1996;493(Pt 3):707-717. [PubMed: 8799893]

82. Avoli M, Louvel J, Pumain R, Kohling R. Cellular and molecular mechanisms of epilepsy in the human brain. Progress in Neurobiology 2005;77:166-200. [PubMed: 16307840]

83. Traynelis SF, Dingledine R. Potassium-induced spontaneous electrographic seizures in the rat hippocampal slice. Journal of Neurophysiology 1988;59:259-276. [PubMed: 3343603]

84. Gomez-Gonzalo M, Losi G, Chiavegato A, Zonta M, Cammarota M, Brondi M, Vetri F, Uva L, Pozzan T, de Curtis M, Ratto GM, Carmignoto G. An excitatory loop with astrocytes contributes to drive neurons to seizure threshold. PLoS biology 2010;8:e1000352. [PubMed: 20405049]

85. Tian GF, Azmi H, Takano T, Xu Q, Peng W, Lin J, Oberheim N, Lou N, Wang X, Zielke HR, Kang J, Nedergaard M. An astrocytic basis of epilepsy. Nature Medicine 2005;11:973-981.

86. Wetherington J, Serrano G, Dingledine R. Astrocytes in the epileptic brain. Neuron 2008;58:168178. [PubMed: 18439402]

87. Oliet SH, Piet R, Poulain DA. Control of glutamate clearance and synaptic efficacy by glial coverage of neurons. Science 2001;292:923-926. [PubMed: 11340204]

88. Fujiwara-Tsukamoto Y, Isomura Y, Kaneda K, Takada M. Synaptic interactions between pyramidal cells and interneurone subtypes during seizure-like activity in the rat hippocampus. The Journal of Physiology 2004;557:961-979. [PubMed: 15107470]

89. Ziburkus J, Cressman JR, Barreto E, Schiff SJ. Interneuron and pyramidal cell interplay during in vitro seizure-like events. Journal of Neurophysiology 2006;95:3948-3954. [PubMed: 16554499]

90. Staley KJ, Soldo BL, Proctor WR. Ionic mechanisms of neuronal excitation by inhibitory GABAa receptors. Science 1995;269:977-981. [PubMed: 7638623]

91. Thompson SM, Gahwiler BH. Activity-dependent disinhibition. I. Repetitive stimulation reduces IPSP driving force and conductance in the hippocampus in vitro. Journal of Neurophysiology 1989;61:501-511. [PubMed: 2709096]

92. Kaila K, Lamsa K, Smirnov S, Taira T, Voipio J. Long-lasting GABA-mediated depolarization evoked by high-frequency stimulation in pyramidal neurons of rat hippocampal slice is attributable to a network-driven, bicarbonate-dependent K+ transient. J Neurosci 1997;17:7662-7672. [PubMed: 9315888]

93. Viitanen T, Ruusuvuori E, Kaila K, Voipio J. The K+-Cl cotransporter KCC2 promotes GABAergic excitation in the mature rat hippocampus. The Journal of Physiology 2010;588:1527-1540. [PubMed: 20211979] 
94. Pinault D, Pumain R. Ectopic action potential generation: Its occurrence in a chronic epileptogenic focus. Experimental Brain Research 1985;60:599-602.

95. Stasheff SF, Hines M, Wilson WA. Axon terminal hyperexcitability associated with epileptogenesis in vitro. I. Origin of ectopic spikes. Journal of Neurophysiology 1993;70:961-975. [PubMed: 8229182]

96. Jefferys JG. Nonsynaptic modulation of neuronal activity in the brain: Electric currents and extracellular ions. Physiological Reviews 1995;75:689-723. [PubMed: 7480159]

97. Haglund MM, Hochman DW. Furosemide and mannitol suppression of epileptic activity in the human brain. Journal of Neurophysiology 2005;94:907-918. [PubMed: 15728766]

98. Hochman DW, Baraban SC, Owens JW, Schwartzkroin PA. Dissociation of synchronization and excitability in furosemide blockade of epileptiform activity. Science 1995;270:99-102. [PubMed: 7569957]

99. Dietzel I, Heinemann U, Hofmeier G, Lux HD. Stimulus-induced changes in extracellular Na+ and $\mathrm{Cl}$ - concentration in relation to changes in the size of the extracellular space. Experimental Brain Research 1982;46:73-84.

100. Khirug S, Ahmad F, Puskarjov M, Afzalov R, Kaila K, Blaesse P. A single seizure episode leads to rapid functional activation of KCC2 in the neonatal rat hippocampus. J Neurosci 2010;30:1202812035. [PubMed: 20826666]

101. Rivera C, Voipio J, Payne JA, Ruusuvuori E, Lahtinen H, Lamsa K, Pirvola U, Saarma M, Kaila K. The $\mathrm{K}+/ \mathrm{Cl}$ - cotransporter $\mathrm{KCC} 2$ renders gaba hyperpolarizing during neuronal maturation. Nature 1999;397:251-255. [PubMed: 9930699]

102. Mizoguchi Y, Ishibashi H, Nabekura J. The action of BDNFon GABA(a) currents changes from potentiating to suppressing during maturation of rat hippocampal CA1 pyramidal neurons. The Journal of Physiology 2003;548:703-709. [PubMed: 12640007]

103. de Curtis M, Manfridi A, Biella G. Activity-dependent pHshifts and periodic recurrence of spontaneous interictal spikes in a model of focal epileptogenesis. J Neurosci 1998;18:7543-7551. [PubMed: 9736672]

104. Ruusuvuori E, Li H, Huttu K, Palva JM, Smirnov S, Rivera C, Kaila K, Voipio J. Carbonic anhydrase isoform VII acts as a molecular switch in the development of synchronous gamma-frequency firing of hippocampal CA1 pyramidal cells. J Neurosci 2004;24:2699-2707. [PubMed: 15028762]

105. Dzhala VI, Brumback AC, Staley KJ. Bumetanide enhances phenobarbital efficacy in a neonatal seizure model. Annals of Neurology 2008;63:222-235. [PubMed: 17918265]

106. Baulac M, Pitkanen A. Research priorities in epilepsy for the next decade-a representative view of the european scientific community. Epilepsia. 2008

107. Schuele SU, Luders HO. Intractable epilepsy: Management and therapeutic alternatives. Lancet Neurology 2008;7:514-524. [PubMed: 18485315]

108. Kahle KT, Staley KJ. The bumetanide-sensitive Na-K-2Cl cotransporter NKCC1 as a potential target of a novel mechanism-based treatment strategy for neonatal seizures. Neurosurg Focus 2008;25:E22. [PubMed: 18759624]

109. Dzhala VI, Talos DM, Sdrulla DA, Brumback AC, Mathews GC, Benke TA, Delpire E, Jensen FE, Staley KJ. NKCC1 transporter facilitates seizures in the developing brain. Nature Medicine 2005;11:1205-1213.

110. Nardou R, Ben-Ari Y, Khalilov I. Bumetanide, an NKCC1 antagonist, does not prevent formation of epileptogenic focus but blocks epileptic focus seizures in immature rat hippocampus. Journal of Neurophysiology 2009;101:2878-2888. [PubMed: 19297515]

111. Brandt C, Nozadze M, Heuchert N, Rattka M, Loscher W. Disease-modifying effects of phenobarbital and the NKCC1 inhibitor bumetanide in the pilocarpine model of temporal lobe epilepsy. J Neurosci 2010;30:8602-8612. [PubMed: 20573906]

112. Kilb W, Sinning A, Luhmann HJ. Model-specific effects of bumetanide on epileptiform activity in the in-vitro intact hippocampus of the newborn mouse. Neuropharmacology 2007;53:524-533.

[PubMed: 17681355] 